\title{
ФАКТОРЫ РИСКА СТЕНОЗА БРАХИОЦЕФАЛЬНЫХ АРТЕРИЙ У БОЛЬНЫХ САХАРНЫМ ДИАБЕТОМ 2 ТИПА
}

\author{
Королева Е.А., Хапаев Р.С., Лыков А.П., Климонтов В.В.
}

Научно-исследовательский институт клинической и экспериментальной медицины — филиал ФИЦ Институт цитологии и генетики СО РАН, Новосибирск

ЦЕЛЬ: изучить распространенность и факторы риска стенозирующего поражения брахиоцефальных артерий у больных сахарным диабетом 2 типа (СД2).

МАТЕРИАЛЫ И МЕТОДЫ: обследовано 390 пациентов с СД2, 277 женщин и 113 мужчин. Средний

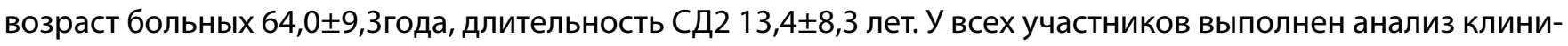
ко-анамнестических и лабораторных данных, ультразвуковое дуплексное сканирование сонных артерий с определением толщины комплекса интима-медиа (ТКИМ) общих сонных артерий, оценкой размеров и количества атеросклеротических бляшек. У 152 пациентов проведено исследование концентрации в сыворотке крови NO, кальпонина-1, релаксина и L-цитруллина. Для определения факторов риска стенозирующего атеросклероза брахиоцефальных артерий (БЦА) у больных СД2 были построены кривые ROC с помощью статистической программы PSPP.

PЕЗУЛЬТАТЫ: по результатам ультразвукового исследования признаки атеросклероза сонных артерий были выявлены у 86\% больных ( $\mathrm{n}=338$ ). У 131 пациента отмечено утолщение КИМ (более 1,0 мм), у 204 атеросклеротические бляшки. У 134 человек (33\%) выявлены стенозы БЦА различной степени выраженности, из них у 39 стенозы являлись гемодинамически значимыми. При сравнении группы больных СД2 с атеросклерозом БЦА без стеноза (группа 1, n=204) и со стенозом БЦА (группа 2, n=134) выявлено,

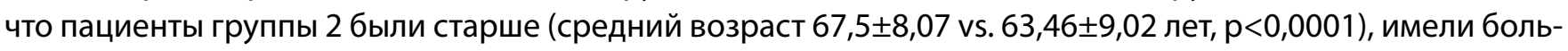

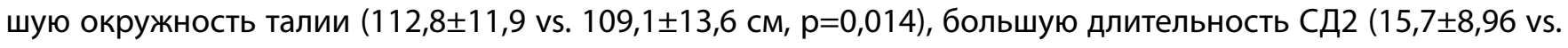
$12,9 \pm 7,8$ лет, $p=0,002)$, более высокий уровень креатинина $(96,5 \pm 31,6$ vs. $89,2 \pm 22,6$ мкмоль/л, $p=0,013)$, от-

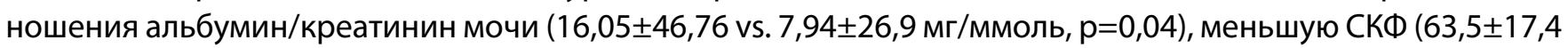
vs. 70,4 18,9 мл/мин ${ }^{*} 1,73$ м² $^{2}$ p=0,0009). Различий по полу, ИМТ, уровню липидов, мочевой кислоты, параметрам гликемического контроля, частоте курения выявлено не было. В группе 2 концентрации в сыворотке

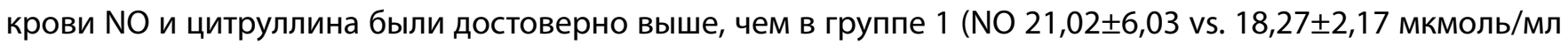
соответственно, $\mathrm{p}=0,005$; цитруллин 202,04 $\pm 211,16$ vs. 90,31 $\pm 131,78$ мкмоль/л соответственно, $\mathrm{p}=0,003$ ). Достоверных различий в уровне кальпонина $(7,1 \pm 3,37$ vs. 7,42 $\pm 3,14$ нг/мл соответственно, $\mathrm{p}=0,58)$ и ре-

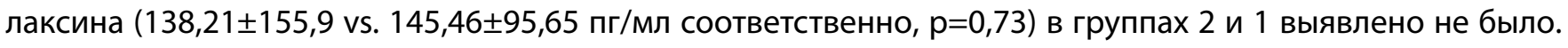
По результатам ROC-анализа в качестве потенциальных факторов риска стенозов БЦА определены возраст (отрезная точка $\geq 65,5$ лет, ОШ 2,62; 1,71-4,03, p $<0,0001$ ), длительность СД2 (отрезная точка $\geq 15,5$ лет, ОШ 2,02; 1,32-3,12, p=0,0013), концентрация NO сыворотки (отрезная точка $\geq 18,23$ мкмоль/мл). При анализе клинических факторов риска развития стеноза БЦА у больных СД2 наиболее значимыми были также

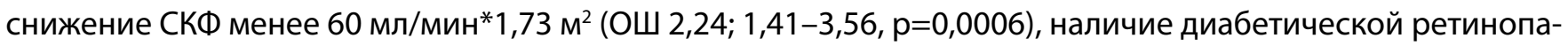
тии (ОШ 1,88; 1,2-2,93, p=0,0057), перенесенного инфаркта миокарда (ОШ 2,64; 1,43-4,88, p=0,002).

Выводы: результаты исследования свидетельствуют о высокой распространенности стенозирующего атеросклероза БЦА среди больных СД2. Возраст старше 65 лет, длительность СД более 15 лет, снижение функции почек, наличие диабетической ретинопатии, перенесенного инфаркта миокарда являются факторами риска каротидного стеноза у больных СД2.

КЛЮЧЕВЫЕ СЛОВА: сахарный диабет; атеросклероз; стеноз брахиочефальных артерий. 